\title{
California calls for nuclear shutdown
}

\section{David Dickson reports from California on reactions to the accident at the Harrisburg nuclear power plant}

THRFe ycars ago, the citizens of Caljfornia voted by a two to one majority against any curb on the development of nuclear power. Last week, following the accident at the Three Mile Island nuclear power plant in Harrisburg, Pennsylvania, which took over a week to bring under control, and resulted in the discharge of radioactive isotopes into the local environment, an informal survey by a San Francisco newspaper based on telephone calls from readers revealed a $56^{\prime \prime}$ majority in favour of shutting down all nuclear power plants.

No one pretends that the California figures are a true reflection of attitudes across the US. California's maverick tradition on "lifestyle" issues, together with a high incidence of sunshine that makes it relatively well placed with respect to alternative sources of energy, both tend to inflate public opposition to nuclear power.

However, the shift in attitude, to judge from press reports, does reflect a public mood. Governor Jerry Brown. his presidential ambitions not far below the surface. has argued with both the Nuclear Regulatory Commission and the local utility company for a temporary shutdown of the Rancho Seco power plant in California (which like the Harrishurg plant was designed by the engineering firm Babcock and Wilcox). And even some of those who had previously been staunch supporters of the nuclear industry are voicing concern that perhaps the Harrisburg incident indicates that not all is as it should - or had been made out--to be.

Defenders of the industry are using the fact that the amount of radiation released to the atmosphere has been minimal, and well below levels claimed to have a harmful effect on humans, to argue that the industry had shown that its safety precautions worked. "Reactors are designed to survive the failure of instruments. which is why they have back up systems." said Dr Edward Teller, so-called "father" of the hydrogen bomb, and now with Stanford University's Hoover Institution. "The worst-case estimate is that some people were exposed to about 50 millirems. Airline hostesses get that in about 50 hours of flight. which they can probably accumulate in about three weeks," Dr Teller said.

But Professor Joseph Rotblat, Emeritus Professor of Physics at St. Bartholomew's Hospital. London University, points out that if the official figure of 25 millirem per hour within a five-mile radius was sustained for the first week of the accident, the 24,000 inhabitants within the five-mile radius could have received a total of 5 rems. This exceeds the maximum allowable dosage for radiation workers of 3 rems in any 13-week period and is ten times the permissable value for the population at large. Official estimates attribute one cancer case per 10,000 population per rem but, says Rotblat, "this estimate is perhaps a factor of ten too small", which would imply an additional 120 cancer cases because of the accident.

If the incident did little to shake the support of firm supporters of nuclear power, neither did it come as much surprised to nuclear critics. "This is just the type of thing that we have been warning people would happen, "said Mr Bob Judd, director of California's Office of Appropriate Technology in Sacrament.

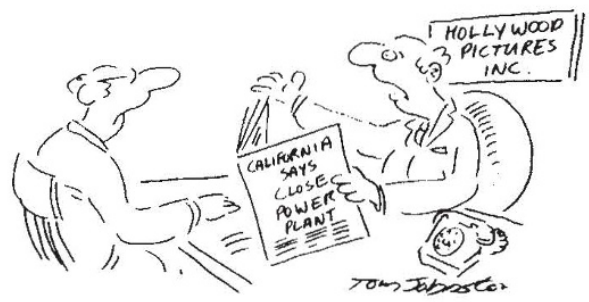

"But we've put a million dollars into Meltdown at Rancho Seco!"

Where there has been a perceptible shift, however, is in those who have yet to come down firmly on one side or another. In the California state legislature, a number of politicians who still support the development of nuclear energy voiced concern at the implications of Harrisburg-for example, at the fact that the formation of the hydrogen bubble which formed at the top of the containment vessel. and gave the greatest source of concern, had never entered anyone's calculations as a potential event-and supported Governor Brown's call for a temporary closure of Rancho Seco.

Similarly on university campuses some of those previously sympathetic to the anti-nuclear movement, but sceptical of its apparent "anti-technology" stance, admitted that the Harrisburg incident had shifted their perspective. "I am beginning to believe that there is something inherently unstable about nuclear power; that unlike other energy sources, the more you develop it, the more you have to develop systems to keep it under control," says Professor Charles Schwarz, professor of physics at the University of California at Berkeley.

The incident hung like a black cloud over the proceedings of a San Francisco conference on "science, technology and the human prospect" which had been organised jointly by the Electric Power Research Institute and the Thomas Alva Edison Foundation as part of a year-long commemoration of the invention of the electric light one hundred years ago.

The opening day of the conference coincided with Governor Brown's call for the closing of Rancho Seco. Dr Chauncey Starr. Vice-President of FPRI, admitted at a press conference that he would have liked to discuss some of the broader issues being raised by the conference. billed as "a unique opportunity to explore the impact of science and technology on society's development". But all the questions, inevitably, turned on Harrisburg.

"Give us the facts. We want facts, not opinions," demanded one journalist, as Dr Starr explained that at present the precise sequence of events within the reactor that had led to the accident was unknown, but assured people that the levels of radiation to which the local community had been exposed were "so low that they were below any physiological danger to anyone, including pregnant women."

The accident did not change the longterm picture, he said. The initiating circumstances-the apparent failure of a pump circulating the cooling waterwas not uncommon, and the statistical probability of the accident fell within the range that had been predicted for the nuclear power programme over 400 reactor years of operation. "Risk analysis is not going to be changed in any particular way by this," Dr Starr said.

"Although something happened in this plant that we do not yet fully understand, no one has been hurt, and there is no public danger that any of us can see. I do not think that shutting down nuclear power plants is a way to increase public confidence. We will continue to do our best to get the public to understand that there are sufficient assets to nuclear power compared to other energy sources, and that the health risks remain very much less. Remember that even steam boilers blow up."

Back in the less charged atmosphere of the conference, speakers talked in general terms about the need to maintain confidence, that society could learn to control the technology that it had developed, and claimed that the Harrisburg incident should reinforce-rather than dent-this confidence (though most were reluctant to get into a detailed discussion of the incident itself). 